\title{
The right of peoples to self-determination and territorial integrity of states in the estimates and conclusions of the Venice commission
}

\begin{abstract}
The article analyzes the thematic reports and conclusions of the European Commission for democracy through law (Venice Commission) on the issue of self-determination of peoples and territorial integrity of the state. The author made a convoy of thematic reports of the Commission and its conclusions on the Crimean referendum in 2014. The article shows that in the interpretation of the Venice Commission the right to self-determination is limited only by national and cultural rights and is understood as the internal self-determination of the people within the existing borders of the state and cannot be an external self-determination through secession. The author on the basis of the legal analysis of the reunification of Crimea with Russia, in contrast to the conclusion of the Venice Commission, came to the conclusion that it is the will of the people is absolute, unlimited. Hence, the principle of popular sovereignty is primary, and the territorial integrity of the state in crisis and destabilizing situations is secondary. It can be limited by the will of the people. This is possible when the withdrawal of a territory from one state and its accession to another state takes on the character of an armed conflict.
\end{abstract}

Keywords: secession, right of peoples to self-determination, territorial integrity of the state, referendum

\section{Review}

Considering the issues of state structure, the European Commission for democracy through law (Venice Commission) has developed principles for determining the legal status of Autonomous entities in unitary and Federal States and standards for the protection of the rights of national minorities. ${ }^{1}$ The concretization of these provisions was reflected in the report Of the Venice Commission of 10-11December 1999 on self-determination and secession in constitutional law. It subordinated the principle of self-determination to the principle of the territorial integrity of States. The Commission did not interpret the right to self-determination in constitutional law as the right to secede from the state. A review of the constitutions of European States in the Report had shown that most of them did not proclaim the right to self-determination, and if they did, they were not linked to the right to secede from the state. In the case of the Declaration of the right to self-determination, the constitutions of such States (Russian Federation, Croatia (V.G.) do not provide for legal mechanisms for its implementation. ${ }^{2}$ Consequently, the right to self-determination is limited only to national and cultural rights and is understood as the internal self-determination of a people within the existing borders of a state and cannot be external self-determination through secession. It should be noted that this correct conclusion of the Venice Commission was the basis of its politicized Opinion of March 21, 2014 on the Crimean referendum, according to which the Constitution of Ukraine, like other constitutions of the member States of the Council of Europe, provides for the integrity of the country and does not allow any local referendum on secession. Under the Constitution of Ukraine, only a consultative referendum on broader autonomy could be permissible. ${ }^{3}$ Therefore, according to the Commission, the referendum on the right of withdrawal (secession) is initially unconstitutional because of its legal nature. The representative of the Russian Federation to the Venice Commission T.Y. khabrieva after the judgement, said that the decision to hold a referendum it is impossible to estimate outside
Volume 7 Issue 2 - 2019

\author{
Goshulyak VV \\ Doctor of law, Dean of the faculty of law, Russia
}

Correspondence: GoshulyakVV, Doctor of law, doctor of history, Professor, Dean of the faculty of law, Russia, Emailvvgoshulyak@rambler.ru

Received: March II, 2019 | Published: March 26, 2019 of historical and legal, the actual constitutional and international legal context, revealing the origins and driving forces taking place in the Crimea; that the February 2014 coup established in Ukraine the situation of constitutional and legal uncertainty and that in such circumstances, the prevailing constitutional and legal significance for the Crimea become the constitutional acts and the will of the people of the Crimea. ${ }^{3}$ As can be seen, the Venice Commission did not take into account the legal supremacy of the will of the people expressed in the referendum when making its decision in 2014. It is the will of the people that is absolute, unlimited. Hence, the principle of popular sovereignty is primary, and the territorial integrity of the state in crisis and destabilizing situations is secondary. It can be limited by the will of the people. This is possible when the withdrawal of a territory from one state and its accession to another state takes on the character of an armed conflict. Moreover, such examples from recent European history were available at the Conclusion of the Commission on the Crimean referendum, namely, the recognition by many countries of the legality of Kosovo's secession from Serbia and the Declaration of its independence in 2008. Here the US and their allies found no violation of international law, leaving the destiny of Russia during the reunification of Crimea. The Commission did not take into account the fact that after the coup d'état of 2014 in Kiev, the Constitution of Ukraine did not act, since its norms did not provide for an unconstitutional coming to power. It should also be noted that at the time of the reunification of Crimea with Russia, it was no longer part of Ukraine, but was an independent sovereign state in accordance with the Declaration of independence of the Autonomous Republic of Crimea and the city of Sevastopol, adopted on March 11, 2014 by the legitimate Supreme Council of the Autonomous Republic of Crimea and the Sevastopol city Council. The Declaration stated that in accordance with the UN Charter and international legal acts enshrining the right of peoples to self-determination, and taking into account the confirmation by the UN international court of justice in respect of Kosovo of July 22, 2010 of the fact that the unilateral 
Declaration of independence by a part of the state does not violate any norms of international law, if as a result of the forthcoming March 16,2014 , the direct will of the peoples of Crimea will be decided on the entry of Crimea, including the Autonomous Republic of Crimea and the city of Sevastopol, into Russia, Crimea after the referendum will be declared an independent and sovereign state with a Republican form of government. The Republic of Crimea as an independent and sovereign state in the case of the relevant results of the referendum will turn to the Russian Federation with a proposal for the adoption of the Republic of Crimea on the basis of the relevant interstate Treaty in the Russian Federation as a new subject of the Russian Federation. ${ }^{4}$ March 17, 2014 was proclaimed an independent sovereign Republic of Crimea, in which the city of Sevastopol had a special status. Article 1 of the Federal constitutional law of 21 March 2014 "on the admission to The Russian Federation of the Republic of Crimea and the formation of new subjects within the Russian Federation-the Republic of Crimea and the city of Federal significance Sevastopol" listed the legal grounds for the admission to Russia of new subjects of the Russian Federation, namely: the results of the all-Crimean referendum, which supported the issue of reunification of Crimea with Russia as a subject of the Russian Federation; The Declaration of independence of the Autonomous Republic of Crimea and city of Sevastopol, and the Treaty between the Russian Federation and the Republic of Crimea about acceptance to the Russian Federation Republic of Crimea and education in the Russian Federation new constituent entities; the proposal of the Republic Crimea and city with special status of Sevastopol about acceptance to the Russian Federation the Republic of Crimea, including the city with special status Sevastopo.

The constitutional Court of the Russian Federation in the resolution of March 19, 2014 on the case of check of constitutionality of the international agreement which did not come into force between the Russian Federation and the Republic of Crimea and formation as a part of the Russian Federation of new subjects recognized this agreement as the relevant Constitution of the Russian Federation both in the order of signing, the conclusion and introduction, and on the content of legal norms. ${ }^{6}$ The constitutional Court of Ukraine, by its decision of March 14, 2014, declared the resolution of the Supreme Council of the Autonomous Republic of Crimea "on holding a General referendum" to be inconsistent with the Constitution of Ukraine. ${ }^{7}$ The court's decision provided the following legal arguments: the sovereignty of Ukraine on its entire territory, the territorial integrity of Ukraine, the Supreme legal force of the Constitution of Ukraine, the people as a source of power, the need for an all-Ukrainian referendum. However, at the time of this decision, the jurisdiction of the constitutional Court of Ukraine did not extend to the Republic of Crimea, which became independent from Ukraine in accordance with the Declaration of independence of March 11, 2014. After the coup d'état, Ukraine disintegrated and lost significant parts of its territory. The Russian Federation has developed constitutional legislation regulating the procedure for the adoption and formation of a new subject of the Russian Federation. According to the Federal constitutional law of December 17, 2001 "on the order of acceptance into the Russian Federation and formation in its structure of the new subject of the Russian Federation" acceptance in the Russian Federation of the new subject represents the procedure providing change of structure of subjects of the Russian Federation as a result of accession to the Russian Federation of the foreign state or its part. Acceptance into the Russian Federation as a new subject of a foreign state or its part is carried out by mutual agreement of the Russian Federation and this foreign state in accordance with the international (interstate) agreement on acceptance into the Russian Federation as a new subject of a foreign state or its part, concluded by the Russian Federation with this foreign state. The initiator of the proposal to accept the Russian Federation as a new subject of a foreign state or part thereof and the conclusion of an international Treaty is this foreign state. ${ }^{8}$ In our case, the Republic of Crimea was admitted to the Russian Federation as a foreign state on a voluntary basis and as a result of a national referendum. Thus, the right to self-determination can be limited by national and cultural rights and understood as the internal self-determination of the people within the existing borders of the state only in the period of stability of the Constitution and the absence of acute crisis phenomena associated with the disintegration of the state. In the case of Ukraine, the reason for its disintegration was not the reunification of Crimea with Russia, but a coup d'état.

\section{Acknowledgments}

None.

\section{Conflicts of interest}

The author declares that there are no conflicts of interest.

\section{References}

1. Venice Commission: one hundred steps towards democracy through law. $2014 ; 255$.

2. Tomsinov VA. International law from the point of view of reunification of Crimea with Russia. Legislation. 2014;7:12-28.

3. Declaration of independence of the Autonomous Republic of Crimea and the city of Sevastopol. Voltaire network. 2014

4. Khabrieva T. Interview with the representative of the Russian Federation in the Venice co-mission.

5. The decision of the constitutional Court of the Russian Federation. On the case about the verification of constitutionality does not come into force international Treaty between the Russian Federation and the Republic of Crimea and education in the Russian Federation new constituent entities. The Russian newspaper. 2014.

6. The decision of the constitutional Court of Ukraine, in the matter about compliance of the Constitution of Ukraine the decree of the Supreme Council of the Autonomous Republic of Crimea On conducting allCrimean referendum. Legislation of Ukraine. 2014.

7. FKZ. On the procedure for acceptance in the Russian Federation and formations in its structure of the new subject of the Russian Federation. Collection of the legislation of the Russian Federation. 2001.

8. FKZ. On the admission of the Russian Federation of the Republic of Crimea and formation as a part of the Russian Federation of new subjects - the Republic of Crimea and the city of Federal value of Sevastopol. Collection of the legislation of the Russian Federation. 2018. 